J Org Chem. 2020 February 07; 85(3): 1718-1724. doi:10.1021/acs.joc.9b02562.

\title{
Preparation of $\beta^{2}$-homologous Amino Acids Bearing Polar Side Chains via a Collective Synthesis Strategy
}

\author{
Shi Liu', Samuel H. Gellman ${ }^{\dagger}$ \\ tDepartment of Chemistry, University of Wisconsin-Madison, WI 53706
}

\begin{abstract}
$\beta$-homologous amino acids ( $\beta$ hAAs) are a valuable class of build blocks for novel analogues of bioactive peptides. Thus, practical methods to synthesize enantiopure $\beta$ hAAs are desirable. We report the application of a collective synthesis strategy to prepare protected $\beta^{2}$-homologous amino acids with polar side chains. In this approach, a core structure is constructed via proline-catalyzed Mannich reaction and subsequently derivatized to furnish more than one protected $\beta^{2}$-homologous amino acid with a proteinogenic side chain.
\end{abstract}

\section{Graphical Abstract}

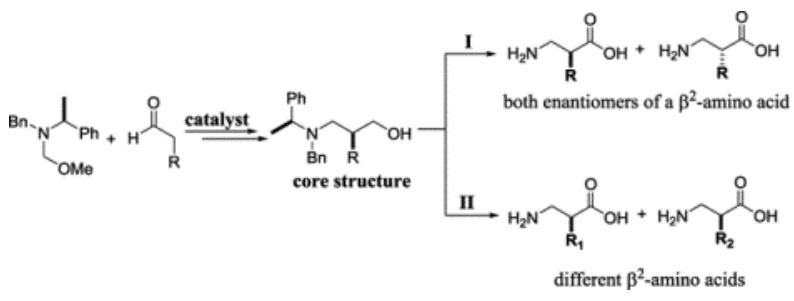

$\beta$-homologous amino acids ( $\beta$ hAAs) are the homologues of $\alpha$-amino acids that bear the same side chain but contain one additional methylene unit in the backbone (Figure 1). There are two classes of $\beta$ hAAs that differ in side chain location. In $\beta^{2}$ hAAs the side chain projects from the carbon adjacent to carbonyl, while in $\beta^{3}$ hAAs the side chain projects from the carbon adjacent to nitrogen. $\beta$-Homologues of the proteinogenic $a$-amino acids have proven to be valuable building blocks for preparation of novel peptides with useful biological activities. ${ }^{1,2} \alpha / \beta$-Peptides that retain the original side chain sequence but contain homologous $\alpha$-to- $\beta$ replacements at one site or more display lower susceptibility to proteolysis relative to the $\alpha$-peptide prototype. ${ }^{3}$ Moreover, such $\alpha / \beta$-peptides can adopt a helical conformation that is very similar to the a-helix, despite the "extra" carbon(s) in the backbone. Perhaps the most intriguing properties discovered among peptides containing homologous $\alpha$-to- $\beta$ replacements arise from subtle alterations in recognition properties. Different patterns of $\alpha$-to- $\beta^{3}$ replacement in the Bim BH3 domain, for example, resulted in diverse binding profiles with partner proteins $\mathrm{Bcl}-\mathrm{x}_{\mathrm{L}}$ and Mcl-1. ${ }^{4} \mathrm{~A}$ 34-residue a-peptide

Corresponding Author: gellman@chem.wisc.edu.

Supporting Information

NMR spectra for all new compounds and crystallographic data for compound 9 
that potently activates both parathyroid hormone receptors, PTHR1 and PTHR2, could be converted to an agonist highly selective for either the PTHR1 or the PTHR2 by two $\alpha$-to- $\beta$ replacements, depending on replacement site and whether $\beta^{2}$ or $\beta^{3}$ residues were used. ${ }^{5}$ Single $\beta$ hAA replacements in PTHR1 agonist peptides generated homologues with a strong bias for $\mathrm{G}$ protein activation relative to $\beta$-arrestin recruitment. ${ }^{6}$

Analogues of bioactive $\alpha$-peptides that contain homologous $\alpha$-to- $\beta$ replacements are readily prepared via conventional solid-phase synthesis methods. This approach, however, depends on access to the necessary protected $\beta$-amino acids. Nearly all $\beta^{3}$ hAA derivatives bearing proteinogenic side chains, and many with non-proteinogenic side chains, are commercially available with protecting groups suitable for Fmoc-based solid-phase synthesis. In contrast, only a small set of $\beta^{2}$ hAA building blocks can be purchased, mostly with hydrocarbon side chains. For this reason, homologues of bioactive a-peptides containing $\beta^{2} \mathrm{hAA}$ replacements have received considerably less attention to date than have homologues containing $\beta^{3} \mathrm{hAA}$ replacements.

Several synthetic strategies have been explored for the preparation of enantiopure $\beta^{2}$ homologous amino acids, but none of reported methods offers practical access to $\beta^{2} \mathrm{hAA}$ building blocks with all of the proteinogenic side chains. ${ }^{7}$ Seebach reported the first approach to $\beta^{2} \mathrm{hAA}$, which involved using the Evans auxiliary to direct the formation of stereocenter. ${ }^{8}$ This method represents an important contribution, but the Evans auxiliarybased strategy has some limitation. First, several synthetic steps were required to access the starting $\mathrm{N}$-acyl amide. Second, the conditions necessary to remove the chiral auxiliary may result in epimerization of stereogenic center. In peptide synthesis, the use of building blocks with even low levels of stereochemical impurities, particularly at multiple positions in the sequence, can lead to complex product mixtures.

Our group previously developed an organocatalytic Mannich reaction-based method to prepare $\beta^{2} h A A s$. The initial version of this strategy employs a chiral organocatalyst, the Jorgensen-Hayashi pyrrolidine derivative, to promote asymmetric a-aminomethylation of aldehydes (Figure 2a). ${ }^{9}$ Following the in situ reduction of the Mannich product, Fmoc protection, and purification, the desired stereoisomer of the 1,3-amino alcohol derivatives is oxidized to the corresponding $\beta^{2} \mathrm{hAA}$. A modified version employs proline as the organocatalysts, and the iminium precursor bears a chiral appendage (Figure $2 b$ ). ${ }^{10}$ The main purpose of the chiral auxiliary is to facilitate purification of 1,3-amino alcohol derivatives generated by the Mannich/reduction sequence, via separation of diastereomers rather than enantiomers. The configuration of the new stereogenic center formed in the Mannich reaction is largely controlled by the organocatalyst (proline, in this case), but small effects on diastereomer ratio were attributed to a matched/mismatched relationship between organocatalyst and auxiliary. The $\beta^{2} \mathrm{hAA}$ syntheses reported here are based on the latter approach.

In the newer version of our method, which makes use of a chiral precursor to the iminium intermediate, the diastereomeric separation of the reduced Mannich product presents as a technical challenge. Purification by crystallization would be desirable, but laborious column chromatography is often required, under conditions specific to each 1,3-amino alcohol. To 
minimize the number of diastereomeric separations required for access to a set of protected $\beta^{2}$ hAAs building blocks, we envisioned a collective strategy in which two or more building blocks would be generated from a common 1,3-amino alcohol intermediate. The examples described here provide access to both enantiomers of protected $\beta^{2}$-homoserine $\left(\beta^{2}\right.$-hSer) from one common intermediate, and to both enantiomers of protected $\beta^{2}$-hGlu and $\beta^{2}$-hGln from another common intermediate. In general, building blocks for $\beta^{2} \mathrm{hAA}$ residues with polar side chains are more difficult to prepare than building blocks for $\beta^{2} \mathrm{hAA}$ residues with hydrocarbon side chains.

The first example of the collective synthesis approach provides both $\beta^{2}$-hSer enantiomers (Figure 3). In this case, the 1,3-amino alcohol derivative generated by the Mannich reaction/ reduction sequence, compound $\mathbf{3}$, can be seen as a 2-substituted derivative of 1,3propanediol in which one of the hydroxyl groups is protected. Carrying this intermediate forward in the usual way, via intermediate 4, provides Fmoc-protected $\left(R^{*}\right)-\beta^{2}$-hSer with a TBS-protected side chain hydroxyl (5). On the other hand, the position and identity of the hydroxyl protecting group can be swapped to generate intermediate $\mathbf{6}$, which can be converted to $\left(S^{*}\right)-\beta^{2}$-hSer with a trityl-protected side chain hydroxyl (7). Both the TBS and trityl groups are suitable for Fmoc-based solid-phase peptide synthesis.

The second example of collective synthesis provides enantiopure $\left(R^{*}\right)-\beta^{2}$-hGlu or $\left(R^{*}\right)-\beta^{2}$ hGln from common core structure $\mathbf{9}$, which can be generated in stereochemically pure form by crystallization after the Mannich sequence (Figure 4). The enantiomer of 9 is available if L-proline and the enantiomeric iminium precursor are employed in the Mannich sequence.

After TBS protection of the hydroxyl group of $\mathbf{9}$, the methyl ester is hydrolyzed under basic conditions. The resulting carboxylic acid is converted to either the tert-butyl ester (for $\beta^{2}$ hGlu as the ultimate goal) or the $\mathrm{N}$-trityl amide (for $\beta^{2}$-hGln as the ultimate goal). The latter path must accommodate the low intrinsic nucleophilicity of tritylamine $\left(\mathrm{TrtNH}_{2}\right)$; we used HATU for carboxylic acid activation, and we found that heating to $60{ }^{\circ} \mathrm{C}$ was necessary. After $N$-debenzylation, Fmoc protection and hydroxyl oxidation, $\mathbf{1 0}$ was converted to the protected $\beta^{2}$-hGlu building block, and 12 was converted to the desired $\beta^{2}$-hGln building block. An unusual catalytic system (a combination of $\mathrm{Pd} / \mathrm{C}$ and $\left.\mathrm{Pd}(\mathrm{OH})_{2} / \mathrm{C}\right)^{11}$ was needed for $N$-debenzylation of $\mathbf{1 2}$.

For structural and functional mimicry of an a-peptide with an a-helical bioactive conformation, the $\left(S^{*}\right)-\beta^{2}$-homologue is better than the $\left(R^{*}\right)-\beta^{2}$-homologue. However, when the bioactive conformation is unknown, we have found that is important to evaluate $\alpha$-to- $\beta$ replacements involving both the $\left(S^{*}\right)-\beta^{2}$-homologue and the $\left(R^{*}\right)-\beta^{2}$-homologue. The collective synthetic routes described here provide access to protected $\beta^{2}$-hSer, $\beta^{2}$-hGlu and $\beta^{2}$-hGln in each enantiomeric form. Each of these enantiopure protected $\beta^{2}$-homologous amino acids has been used to construct analogues of the osteoporosis drug PTH(1-34), and these analogues have been shown to display distinctive physical and pharmacological properties. ${ }^{5}$ The availability of these building blocks should enable the discovery of new protease-resistant analogues of peptide hormones and other useful molecules. 


\section{Experimental Section}

\section{General Procedures:}

Unless otherwise stated, all reactions were performed in oven-dried round-bottom glass flasks. TBS deprotection reactions were performed in plastic reaction vessels with TBAF. Oil bath was used for reactions that required heating.

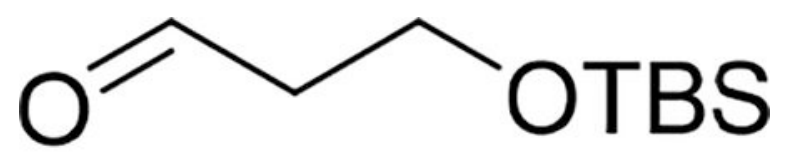

3-(tert-Butyldimethylsiloxy)-propionaldehyde (1): Prepared from 3-(tertbutyldimethylsiloxy)-propanol ${ }^{12}$ by Cu/TEMPO oxidation. ${ }^{13}$ To a solution of 3-(tertbutyldimethylsiloxy)-propanol ( $12.5 \mathrm{~g}, 65.7 \mathrm{mmol})$ in $200 \mathrm{ml} \mathrm{CH}_{3} \mathrm{CN}$ were added $\mathrm{CuBr}$ (0.47 g, $3.3 \mathrm{mmol}), 2$,'-bipyridine (0.52 g, $3.3 \mathrm{mmol})$, TEMPO (2,2,6,6-Tetramethyl-1piperidinyloxy, $0.52 \mathrm{~g}, 3.3 \mathrm{mmol})$ and 1-methylimidazole $(0.27 \mathrm{~g}, 3.3 \mathrm{mmol})$ sequentially. The resulting solution had a dark brown color at this point. The reaction mixture turned to a green color after being stirred under air overnight, which indicated reaction completion. To the reaction solution was added pentane and water. The aqueous layer was separated and extracted several times with pentane. All the organic layers were combined, dried over anhydrous sodium sulfate, and concentrated to afford compound $\mathbf{1}$ as a colorless oil in good purity $\left(11.2 \mathrm{~g}, 90 \%\right.$ yield). ${ }^{1} \mathrm{H}$ NMR $\left(500 \mathrm{MHz}, \mathrm{CDCl}_{3}\right) \delta 9.81(\mathrm{~s}, 1 \mathrm{H}), 3.99(\mathrm{t}, J=6.0 \mathrm{~Hz}$, $2 \mathrm{H}), 2.60(\mathrm{td}, J=6.0,2.1 \mathrm{~Hz}, 2 \mathrm{H}), 0.89(\mathrm{~s}, 9 \mathrm{H}), 0.07(\mathrm{~s}, 6 \mathrm{H}) ;{ }^{13} \mathrm{C}\left\{{ }^{1} \mathrm{H}\right\} \mathrm{NMR}(125 \mathrm{MHz}$, $\left.\mathrm{CDCl}_{3}\right) \delta 202.1,57.4,46.6,25.8,18.3,-5.4$. The spectral data (provided in the Supporting Information) were consistent with a previous report. ${ }^{14}$
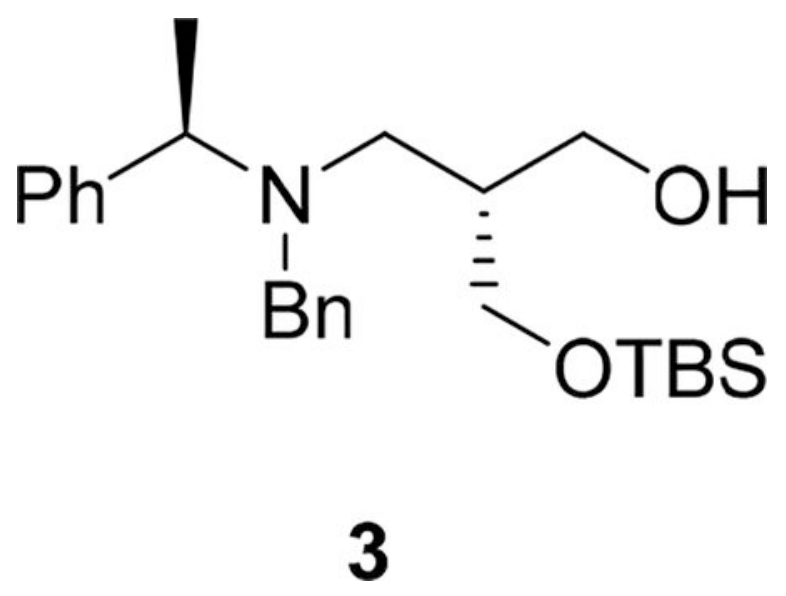

(R)-2-(tert-Butyldimethylsiloxymethyl)-3-(R)-(N-benzyl-amethylbenzylamino)propan-1-ol (3): $\mathrm{N}, O$-Acetal (2) was prepared by using the 
reported protocol..$^{9}$ A suspension of D-proline $(0.69 \mathrm{~g}, 6 \mathrm{mmol})$ in DMF was stirred at room temperature for several hours and then cooled to $-25^{\circ} \mathrm{C}$. To the above mixture was sequentially added $\mathbf{1}(9.4 \mathrm{~g}, 50 \mathrm{mmol})$ and $\mathbf{2}(7.7 \mathrm{~g}, 30 \mathrm{mmol})$. The reaction temperature was maintained around $-25{ }^{\circ} \mathrm{C}$ and reaction progress was monitored by the NMR of the aliquots from the reaction mixture. Upon the complete conversion of the limiting reagent, $\mathrm{NaBH}_{4}$ $(3.4 \mathrm{~g}, 90 \mathrm{mmol})$ and methanol were added to the solution. The resulting mixture was stirred for 0.5 hour at $0{ }^{\circ} \mathrm{C}$ and then slowly transferred to saturated solution of ammonium chloride. The aqueous solution were extracted several times with $\mathrm{Et}_{2} \mathrm{O}$. The organic layers were combined, dried over anhydrous $\mathrm{MgSO}_{4}$, and concentrated. The residue was purified by column chromatography (2-5\% ethyl acetate in hexane) to provide major diastereomer $\mathbf{3}$ as a colorless oil in 52\% yield. ${ }^{1} \mathrm{H}$ NMR $\left(400 \mathrm{MHz}, \mathrm{CDCl}_{3}\right) \delta 7.32-7.24(\mathrm{~m}, 10 \mathrm{H}), 4.07(\mathrm{~s}$, $1 \mathrm{H}), 3.99(\mathrm{q}, J=6.9 \mathrm{~Hz}, 1 \mathrm{H}), 3.78(\mathrm{~d}, J=13.5 \mathrm{~Hz}, 1 \mathrm{H}), 3.59-3.55(\mathrm{~m}, 1 \mathrm{H}), 3.50(\mathrm{dd}, J=$ $10.0,5.1 \mathrm{~Hz}, 1 \mathrm{H}), 3.44(\mathrm{~d}, J=13.5 \mathrm{~Hz}, 1 \mathrm{H}), 3.40(\mathrm{dd}, J=10.0,6.5 \mathrm{~Hz}, 1 \mathrm{H}), 3.31(\mathrm{dd}, J=$ $10.7,6.9 \mathrm{~Hz}, 1 \mathrm{H}), 2.56(\mathrm{dd}, J=13.0,4.9 \mathrm{~Hz}, 1 \mathrm{H}), 2.45(\mathrm{dd}, J=13.0,10.0 \mathrm{~Hz}, 1 \mathrm{H}), 2.09-$ $2.02(\mathrm{~m}, 1 \mathrm{H}), 1.36(\mathrm{~d}, J=6.9 \mathrm{~Hz}, 3 \mathrm{H}), 0.85(\mathrm{~s}, 9 \mathrm{H}), 0.00(\mathrm{~s}, 6 \mathrm{H}) .{ }^{13} \mathrm{C}\left\{{ }^{1} \mathrm{H}\right\} \mathrm{NMR}(125 \mathrm{MHz}$, $\left.\mathrm{CDCl}_{3}\right) \delta 142.5,139.2,129.1,128.4,128.14,128.13,127.2,127.0,65.8,64.2,56.6,54.9$, 50.0, 40.0, 25.8, 18.2, 19.8, -5.53, -5.55. HRMS (ESI): $[\mathrm{M}+\mathrm{H}]^{+}$calculated 414.2823, found 414.2821 .

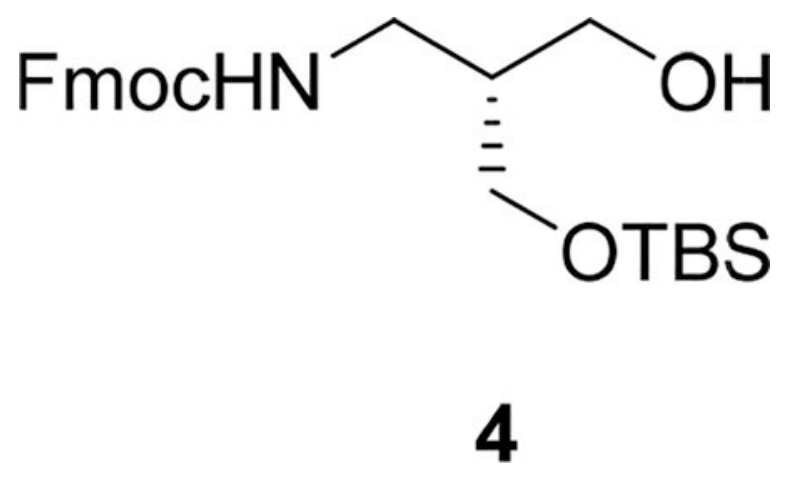

(R)-2-(tert-Butyldimethylsiloxymethyl)-3-(9-fluorenylmethylcarbamate)propan-1-ol (4): To a solution of $\mathbf{3}$ (1.3 g, $3 \mathrm{mmol})$ in $30 \mathrm{ml}$ ethanol was added $0.32 \mathrm{~g}$ $\mathrm{Pd} / \mathrm{C}$ (10 wt. \% loading), $0.21 \mathrm{~g} \mathrm{Pd}(\mathrm{OH})_{2} / \mathrm{C}(20 \%$ wt. \% loading) and ammonium formate $(1.9 \mathrm{~g}, 30 \mathrm{mmol})$. The resulting mixture was stirred for 6 hours at $60{ }^{\circ} \mathrm{C}$ under nitrogen. After the hydrogenolysis was complete, the reaction mixture was filtered through celite, and the celite was washed several times with methanol. The methanol solutions were combined and concentrated. The resulting residue was dissolved in $15 \mathrm{ml} \mathrm{CH}_{2} \mathrm{Cl}_{2}$ with Fmoc-OSu (1 $\mathrm{g}, 3 \mathrm{mmol})$ and DIEA $(0.53 \mathrm{ml}, 3 \mathrm{mmol})$. This solution was stirred for 2 hours at room temperature. The solution was diluted with $\mathrm{CH}_{2} \mathrm{Cl}_{2}$ and washed with brine. The organic layer was separated, dried over anhydrous $\mathrm{MgSO}_{4}$, and concentrated. The residue was purified by column chromatography (25-35\% ethyl acetate in hexane) to provide 4 in $83 \%$ yield as a colorless oil. ${ }^{1} \mathrm{H} \mathrm{NMR}\left(300 \mathrm{MHz}, \mathrm{CDCl}_{3}\right) \delta 7.76(\mathrm{~d}, J=7.4 \mathrm{~Hz}, 2 \mathrm{H}), 7.59$ (d, $J=$ $7.4 \mathrm{~Hz}, 2 \mathrm{H}), 7.40(\mathrm{t}, J=7.4 \mathrm{~Hz}, 2 \mathrm{H}), 7.31(\mathrm{t}, J=7.4 \mathrm{~Hz}, 2 \mathrm{H}), 5.17(\mathrm{~s}, 1 \mathrm{H}), 4.43(\mathrm{~d}, J=6.8$ $\mathrm{Hz}, 2 \mathrm{H}), 4.21(\mathrm{t}, J=6.8 \mathrm{~Hz}, 1 \mathrm{H}), 3.70-3.62(\mathrm{~m}, 4 \mathrm{H}), 3.45-3.26(\mathrm{~m}, 2 \mathrm{H}), 2.83(\mathrm{~s}, 1 \mathrm{H}), 1.87$ (m, 1H), $0.90(\mathrm{~s}, 9 \mathrm{H}), 0.07$ (s, 6H). ${ }^{13} \mathrm{C}\left\{{ }^{1} \mathrm{H}\right\} \mathrm{NMR}\left(125 \mathrm{MHz}, \mathrm{CDCl}_{3}\right) \delta$ 157.4, 143.8, 141.3, 127.7, 127.0, 125.0, 120.0, 66.7, 63.9, 61.9, 47.3, 42.9, 39.8, 25.8, 18.2, -5.6. HRMS 
(ESI): $[\mathrm{M}+\mathrm{H}]^{+}$calculated 442.2408, found 442.2406; $[\mathrm{M}+\mathrm{Na}]^{+}$calculated 464.2228, found 464.2228 .
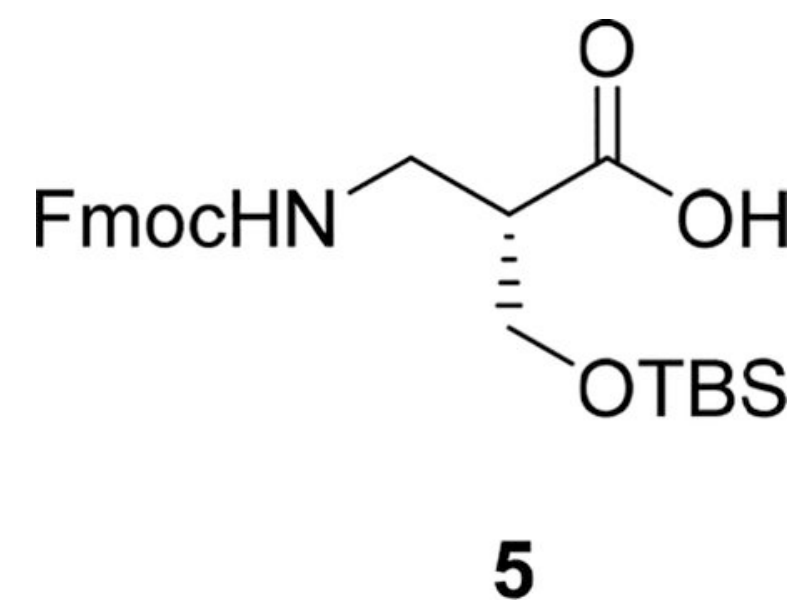

(S)-2-(tert-Butyldimethylsiloxymethyl)-3-(9-fluorenylmethylcarbamate)propanoic acid (5): Prepared from 4 via $\mathrm{RuCl}_{3} / \mathrm{NaIO}_{4}$ oxidation. ${ }^{15}$ A round-bottom flask was charged with $6 \mathrm{ml}$ carbon tetrachloride, $6 \mathrm{ml}$ acetonitrile, $9 \mathrm{ml}$ water, $4(0.97 \mathrm{~g}, 2.2$ $\mathrm{mmol})$ and $\mathrm{NaIO}_{4}(2.1 \mathrm{~g}, 9.9 \mathrm{mmol})$. To this mixture was added $\mathrm{RuCl}_{3}(11 \mathrm{mg}, 0.055$ $\mathrm{mmol})$. The reaction mixture was stirred at room temperature until TLC analysis revealed the complete conversion of the starting alcohol. The reaction mixture was then diluted with ethyl acetate and the remaining oxidant was quenched by adding $0.5 \mathrm{~N}$ aqueous $\mathrm{Na}_{2} \mathrm{~S}_{2} \mathrm{O}_{3}$. The organic layer was separated, and the aqueous layer was extracted several times with ethyl acetate. All organic layers were combined, dried over anhydrous $\mathrm{MgSO}_{4}$, filtered through celite, and concentrated. The residue was purified by column chromatography (25\% ethyl acetate in hexane with $1 \%$ acetic acid) to yield $\mathbf{5}$ as white foam in $67 \%$ yield. ${ }^{1} \mathrm{H}$ NMR (400 MHz, DMSO- $\left.d_{6}\right) \delta 12.30(\mathrm{~s}, 1 \mathrm{H}), 7.88(\mathrm{~d}, J=7.3 \mathrm{~Hz}, 2 \mathrm{H}), 7.67$ (d, $\left.J=7.5 \mathrm{~Hz}, 2 \mathrm{H}\right)$, $7.42-7.35(\mathrm{~m}, 3 \mathrm{H}), 7.31(\mathrm{td}, J=7.5,1.2 \mathrm{~Hz}, 2 \mathrm{H}), 4.30-4.17(\mathrm{~m}, 3 \mathrm{H}), 3.75-3.68(\mathrm{~m}, 2 \mathrm{H})$, 3.23-3.09 (m, 2H), $2.63-2.57(\mathrm{~m}, 1 \mathrm{H}), 0.83(\mathrm{~s}, 1 \mathrm{H}),-0.00(\mathrm{~s}, 1 \mathrm{H}) .{ }^{13} \mathrm{C}\left\{{ }^{1} \mathrm{H}\right\}$ NMR $(125$ MHz, DMSO- $\left.d_{6}\right) \delta 174.1,156.6,144.3,141.2,128.1,127.5,125.6,120.6,65.8,62.3,48.4$, 47.2, 26.2, 18.4, -5.02, -5.04. $[\mathrm{a}]_{\mathrm{D}}{ }^{20}=-2.6\left(\mathrm{c}=4.6, \mathrm{CHCl}_{3}\right)$. HRMS (ESI): $[\mathrm{M}-\mathrm{H}]^{-}$ calculated 454.2055, found 454.2060. 

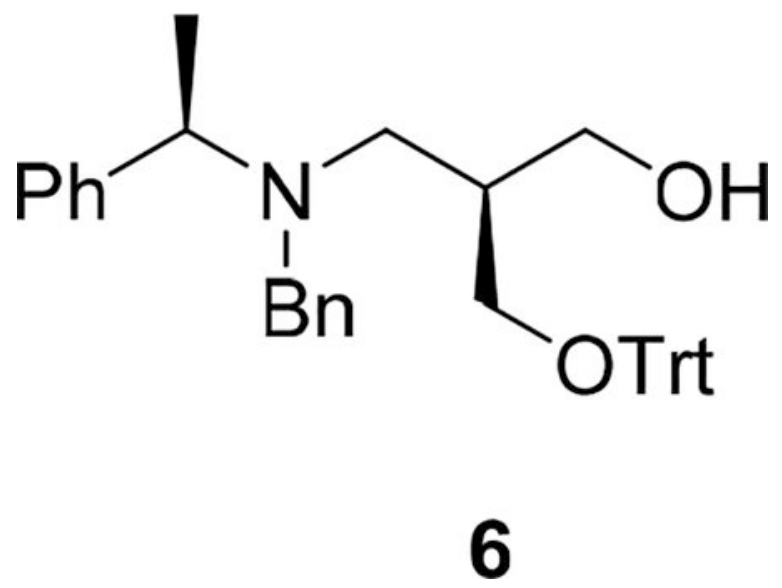

(S)-2-(Triphenylmethoxymethyl)-3-(R)-(N-benzyl-a-

methylbenzylamino)propan-1-ol (6): To a solution of $\mathbf{4}(1.24 \mathrm{~g}, 3 \mathrm{mmol})$ in $30 \mathrm{ml}$

$\mathrm{CH}_{2} \mathrm{Cl}_{2}$ were added trityl chloride $(1.1 \mathrm{~g}, 3.9 \mathrm{mmol})$, DMAP (37 mg, $\left.0.3 \mathrm{mmol}\right)$ and triethyl amine $(0.63 \mathrm{ml}, 4.5 \mathrm{mmol})$. This mixture was stirred overnight at room temperature. The solution was then diluted with $\mathrm{CH}_{2} \mathrm{Cl}_{2}$ and washed with brine. The organic layer was separated, dried over anhydrous $\mathrm{MgSO}_{4}$, and concentrated. The residue was purified by column chromatography ( $2.5 \%$ ethyl acetate in hexane) to afford the pure tritylation product (1.8 g, 91\% yield). ${ }^{1} \mathrm{H}$ NMR (500 MHz, $\left.\mathrm{CDCl}_{3}\right) \delta 7.38-7.37(\mathrm{~m}, 6 \mathrm{H}), 7.29-7.19(\mathrm{~m}, 19 \mathrm{H})$, $3.85(\mathrm{q}, J=6.8 \mathrm{~Hz}, 1 \mathrm{H}), 3.67-3.65(\mathrm{~m}, 2 \mathrm{H}), 3.46(\mathrm{~m}, 2 \mathrm{H}), 3.15(\mathrm{dd}, J=9.0,4.7 \mathrm{~Hz}, 1 \mathrm{H})$, $2.73(\mathrm{t}, J=8.4 \mathrm{~Hz}, 1 \mathrm{H}), 2.55(\mathrm{dd}, J=13.2,6.0 \mathrm{~Hz}, 1 \mathrm{H}), 2.19(\mathrm{dd}, J=13.2,7.8 \mathrm{~Hz}, 1 \mathrm{H}), 2.02$ $(\mathrm{m}, 1 \mathrm{H}), 1.32(\mathrm{~d}, J=6.8 \mathrm{~Hz}, 6 \mathrm{H}), 0.80(\mathrm{~s}, 9 \mathrm{H}),-0.01(\mathrm{~s}, 3 \mathrm{H}),-0.04(\mathrm{~s}, 3 \mathrm{H}) .{ }^{13} \mathrm{C}\left\{{ }^{1} \mathrm{H}\right\}$ NMR $\left(125 \mathrm{MHz}, \mathrm{CDCl}_{3}\right) \delta 144.4,142.9,140.6,128.8,128.1,128.0,127.7,127.6,126.7,126.6$, 126.4, 86.2, 62.7, 62.5, 56.9, 54.7, 48.8, 40.9, 25.9, 18.2, 12.9, -5.4, -5.5. HRMS (ESI): [M $+\mathrm{H}]^{+}$calculated 656.3918 , found 656.3918 .

To a plastic reaction vessel containing a solution of the above tritylation product (1.6 g, 2.4 $\mathrm{mmol}$ ) in $6 \mathrm{ml}$ THF was added TBAF ( $1 \mathrm{M}$ in THF, $4 \mathrm{ml}, 4 \mathrm{mmol}$ ) dropwise. The mixture was stirred at room temperature for 6 hours. To this solution was added ethyl acetate and water. The organic layer was separated, and the aqueous layer was extracted with ethyl acetate several times. All organic layers were combined, dried over anhydrous $\mathrm{MgSO}_{4}$, and concentrated. The residue was purified by column chromatography (10-20\% ethyl acetate in hexane) to afford compound 6 in $87 \%$ yield. ${ }^{1} \mathrm{H}$ NMR $\left(500 \mathrm{MHz}, \mathrm{CDCl}_{3}\right) \delta 7.36$ (d, $J=7.7$ $\mathrm{Hz}, 6 \mathrm{H}), 7.33-7.17$ (m, 19H), 4.79 (s, 1H), 4.00 (q, $J=7.0 \mathrm{~Hz}, 1 \mathrm{H}), 3.85$ (d, $J=13.5 \mathrm{~Hz}$, $1 \mathrm{H}), 3.70(\mathrm{dd}, J=10.5,4.0 \mathrm{~Hz}, 1 \mathrm{H}), 3.50(\mathrm{dd}, J=10.5,7.7 \mathrm{~Hz}, 1 \mathrm{H}), 3.10(\mathrm{~d}, J=13.5 \mathrm{~Hz}$, $1 \mathrm{H}), 2.98(\mathrm{dd}, J=9.2,5.0 \mathrm{~Hz}, 1 \mathrm{H}), 2.81(\mathrm{dd}, J=9.2,6.3 \mathrm{~Hz}, 1 \mathrm{H}), 2.59$ (dd, $J=14.1,11.0$ $\mathrm{Hz}, 1 \mathrm{H}), 2.31(\mathrm{~m}, 2 \mathrm{H}), 1.49(\mathrm{~d}, J=7.0 \mathrm{~Hz}, 3 \mathrm{H}) .{ }^{13} \mathrm{C}\left\{{ }^{1} \mathrm{H}\right\} \mathrm{NMR}\left(125 \mathrm{MHz}, \mathrm{CDCl}_{3}\right) \delta 143.9$, 139.8, 138.9, 129.0, 128.6, 128.5, 128.4, 128.1, 127.8, 127.2, 127.1, 127.0, 86.6, 66.7, 64.1, 57.6, 54.7, 52.0, 38.2, 17.1. HRMS (ESI): $[\mathrm{M}+\mathrm{H}]^{+}$calculated 542.3054, found 542.3054. 

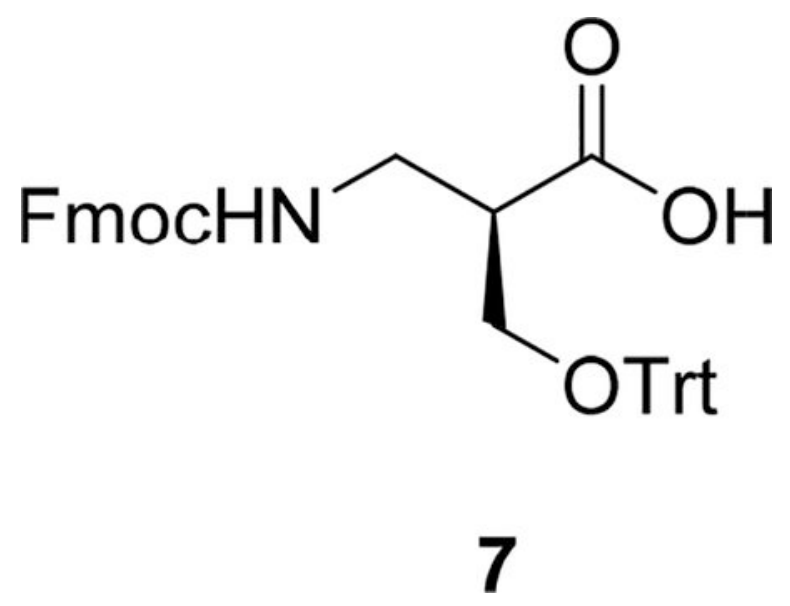

(R)-2-(Triphenylmethoxymethyl)-3-(9-fluorenylmethylcarbamate)-propanoic acid (7): To a solution of $6(1.1 \mathrm{~g}, 2 \mathrm{mmol})$ in $20 \mathrm{ml}$ ethanol were added $0.21 \mathrm{~g} \mathrm{Pd} / \mathrm{C}(10$ wt. \% loading), $0.14 \mathrm{~g} \mathrm{Pd}(\mathrm{OH})_{2} / \mathrm{C}(20 \%$ wt. \% loading) and ammonium formate $(1.2 \mathrm{~g}, 20$ $\mathrm{mmol})$. The resulting mixture was stirred for 4 hours at $60^{\circ} \mathrm{C}$ under nitrogen. After the hydrogenolysis was complete, the reaction mixture was filtered through celite, and the celite was washed several times with methanol. The methanol solutions were combined and concentrated. The resulting residue was dissolved in $20 \mathrm{ml} \mathrm{CH}_{2} \mathrm{Cl}_{2}$ with Fmoc-OSu ( $0.68 \mathrm{~g}$, $2 \mathrm{mmol}$ ) and DIEA ( $0.35 \mathrm{ml}, 2 \mathrm{mmol})$. The above solution was stirred for 2 hours at room temperature. The reaction mixture was diluted with $\mathrm{CH}_{2} \mathrm{Cl}_{2}$ and washed several times with brine. The organic layer was separated, dried over anhydrous $\mathrm{MgSO}_{4}$, and concentrated. The residue was purified by column chromatography (25-35\% ethyl acetate in hexane) to provide the desired product in $77 \%$ yield. ${ }^{1} \mathrm{H}$ NMR $\left(400 \mathrm{MHz}, \mathrm{CDCl}_{3}\right) \delta 7.76(\mathrm{~d}, J=7.4$ $\mathrm{Hz}, 2 \mathrm{H}), 7.53$ (d, $J=7.4 \mathrm{~Hz}, 2 \mathrm{H}), 7.44-7.38(\mathrm{~m}, 8 \mathrm{H}), 7.30$ (t, $J=7.4 \mathrm{~Hz}, 8 \mathrm{H}), 7.23$ (t, $J=$ $7.4 \mathrm{~Hz}, 3 \mathrm{H}), 4.62(\mathrm{t}, J=6.5 \mathrm{~Hz}, 1 \mathrm{H}), 4.39(\mathrm{~d}, J=6.7 \mathrm{~Hz}, 2 \mathrm{H}), 4.17(\mathrm{t}, J=6.7 \mathrm{~Hz}, 1 \mathrm{H}), 3.56$ (m, 1H), 3.48-3.37 (m, 2H), 3.28-3.20 (m, 2H), 3.08 (dd, $J=9.4,7.2 \mathrm{~Hz}, 1 \mathrm{H}), 2.86(\mathrm{~s}, 1 \mathrm{H})$, $1.99(\mathrm{~m}, 1 \mathrm{H}) .{ }^{13} \mathrm{C}\left\{{ }^{1} \mathrm{H}\right\}$ NMR $\left(125 \mathrm{MHz}, \mathrm{CDCl}_{3}\right) \delta 157.5,143.83,143.80,143.7,141.3$, 128.5, 127.9, 127.7, 127.2, 127.0, 124.9, 120.0, 86.9, 66.6, 62.4, 61.3, 47.3, 42.0, 39.3. HRMS (ESI): $[\mathrm{M}+\mathrm{Na}]^{+}$calculated 592.2458, found 592.2459.

The Fmoc-protected amino alcohol intermediate was converted to 7 via Jones oxidation. A solution of Fmoc-protected amino alcohol $(0.65 \mathrm{~g}, 1.1 \mathrm{mmol})$ in $20 \mathrm{ml}$ acetone was added dropwise to $2.3 \mathrm{mmol} \mathrm{H}_{2} \mathrm{Cr}_{2} \mathrm{O}_{7}$ (prepared by mixing $\mathrm{Na}_{2} \mathrm{Cr}_{2} \mathrm{O}_{7} \cdot 2 \mathrm{H}_{2} \mathrm{O}$ and $\mathrm{H}_{2} \mathrm{SO}_{4}$ ) in 30 $\mathrm{ml}$ acetone at $0{ }^{\circ} \mathrm{C}$. The reaction mixture was stirred for several hours until TLC analysis revealed the complete conversion of the starting alcohol. Excess isopropanol was then added to quench the remaining oxidant. To this mixture were added ethyl acetate and water. The organic layer was separated, and the aqueous layer was extracted with ethyl acetate several times. All organic layers were combined, washed with brine, dried over anhydrous $\mathrm{MgSO}_{4}$, filtered through celite, and concentrated. The residue was purified by column chromatography (35\% ethyl acetate in hexane with $1 \%$ acetic acid) to afford $\mathbf{7}$ as a white solid in $47 \%$ yield. ${ }^{1} \mathrm{H}$ NMR (300 MHz, DMSO- $\left.d_{6}\right) \delta 12.46(\mathrm{~s}, 1 \mathrm{H}), 7.88(\mathrm{~d}, J=7.4 \mathrm{~Hz}$, $2 \mathrm{H}), 7.65(\mathrm{~d}, J=7.4 \mathrm{~Hz}, 2 \mathrm{H}), 7.41(\mathrm{t}, J=7.4 \mathrm{~Hz}, 2 \mathrm{H}), 7.36-7.21(\mathrm{~m}, 17 \mathrm{H}), 4.24(\mathrm{~d}, J=6.8$ $\mathrm{Hz}, 2 \mathrm{H}), 4.17(\mathrm{t}, J=6.8 \mathrm{~Hz}, 1 \mathrm{H}), 3.24-3.11(\mathrm{~m}, 4 \mathrm{H}), 2.77-2.69(\mathrm{~m}, 1 \mathrm{H}) .{ }^{13} \mathrm{C}\left\{{ }^{1} \mathrm{H}\right\} \mathrm{NMR}$ 
$\left(125 \mathrm{MHz}, \mathrm{DMSO}-d_{6}\right) \delta 173.7,156.0,143.83,143.81,143.6,140.7,128.1,127.8,127.6$, $127.02,127.00,125.1,120.1,85.8,65.4,62.1,46.6,45.8 .[a]_{\mathrm{D}}{ }^{20}=-3.7\left(\mathrm{c}=2.5, \mathrm{CHCl}_{3}\right)$. HRMS (ESI): [M - H] $]^{-}$calculated 582.2286, found 582.2285.
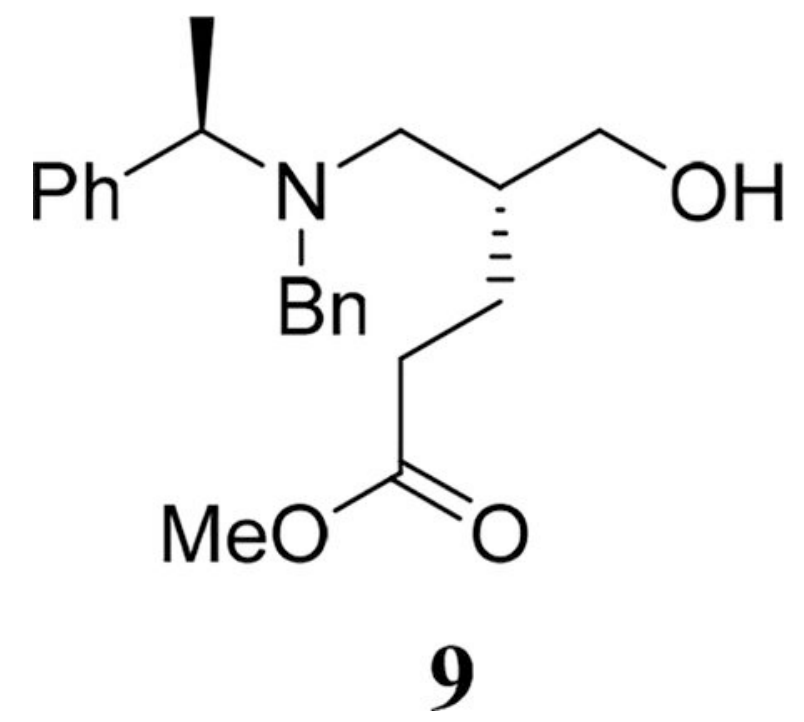

\section{(R)-2-(Carboxyethyl-methyl ester)-3-( $R$ )-(N-benzyl-a-} methylbenzylamino)propan-1-ol (9): A suspension of D-proline $(0.96 \mathrm{~g}, 8.4 \mathrm{mmol})$ in $400 \mathrm{ml}$ DMF was stirred at room temperature for several hours and then cooled to $-25^{\circ} \mathrm{C}$. To this mixture was sequentially added $\mathbf{8}^{16}(9.2 \mathrm{~g}, 71 \mathrm{mmol})$ and $\mathbf{2}(10.8 \mathrm{~g}, 42 \mathrm{mmol})$. The reaction temperature was maintained around $-25^{\circ} \mathrm{C}$ and reaction progress was monitored by the NMR of the aliquots from the reaction mixture. Upon the complete conversion of the limiting reagent $2, \mathrm{NaBH}_{4}(4.5 \mathrm{~g}, 0.12 \mathrm{~mol})$ and $100 \mathrm{ml}$ methanol were added to the reaction solution. This mixture was stirred for 1 hour at $0{ }^{\circ} \mathrm{C}$ and then slowly transferred to saturated solution of ammonium chloride. The aqueous solution were extracted several times with $\mathrm{Et}_{2} \mathrm{O}$. The organic layers were combined, dried over anhydrous $\mathrm{MgSO}_{4}$, and concentrated. Silica gel column chromatography was then used to remove the residual DMF and N-benzyla-methylbenzylamine (side product from retro-Michael reaction of the Mannich adduct). This chromatography step is important for efficient crystallization of $\mathbf{9}$ from hexane/diethyl ether. To induce crystallization, a hexane suspension of the crude product in a round-bottom flask was heated. To this mixture was added diethyl ether in dropwise fashion with shaking until a homogenous solution had formed. The resulting solution was placed in a refrigerator to allow crystallization. Compound $\mathbf{9}$ was isolated as white, crystalline solid in $45 \%$ yield. ${ }^{1} \mathrm{H}$ NMR $\left(400 \mathrm{MHz}, \mathrm{CDCl}_{3}\right) \delta 7.36-7.23(\mathrm{~m}, 10 \mathrm{H}), 4.56(\mathrm{~s}, 1 \mathrm{H}), 4.00(\mathrm{q}, J=6.8 \mathrm{~Hz}, 1 \mathrm{H})$, $3.88(\mathrm{~d}, J=13.1 \mathrm{~Hz}, 1 \mathrm{H}), 3.65(\mathrm{~s}, 3 \mathrm{H}), 3.56(\mathrm{~m}, 1 \mathrm{H}), 3.39(\mathrm{~d}, J=13.1 \mathrm{~Hz}, 1 \mathrm{H}), 3.02(\mathrm{dd}, J=$ $10.8,8.2 \mathrm{~Hz}, 1 \mathrm{H}), 2.55(\mathrm{~m}, 1 \mathrm{H}), 2.46(\mathrm{dd}, J=12.9,10.8 \mathrm{~Hz}, 1 \mathrm{H}), 2.28(\mathrm{t}, J=7.7 \mathrm{~Hz}, 2 \mathrm{H})$, $1.87(\mathrm{~m}, 1 \mathrm{H}), 1.45-1.27(\mathrm{~m}, 5 \mathrm{H}) .{ }^{13} \mathrm{C}\left\{{ }^{1} \mathrm{H}\right\}$ NMR $\left(125 \mathrm{MHz}, \mathrm{CDCl}_{3}\right) \delta 174.0,142.6,138.8$, 129.4, 128.7, 128.4, 128.3, 127.5, 127.3, 67.1, 56.5, 55.2, 53.9, 51.8, 36.5, 31.9, 25.1, 9.7. HRMS (ESI): $[\mathrm{M}+\mathrm{H}]^{+}$calculated 356.2220, found 356.2217.

Crystals from the preparative crystallization were suitable for x-ray diffraction; and the x-ray diffraction structure of $\mathbf{9}$ is shown in the Supporting Information. The crystal structure 
allowed us to establish the new asymmetric center as having $\mathrm{R}$ configuration, which was consistent with our previous report that the use of L-proline and the enantiomeric iminium precursor enabled the preparation of the 1,3-amino alcohol derivatives with the opposite configuration at the new asymmetric center. ${ }^{10}$

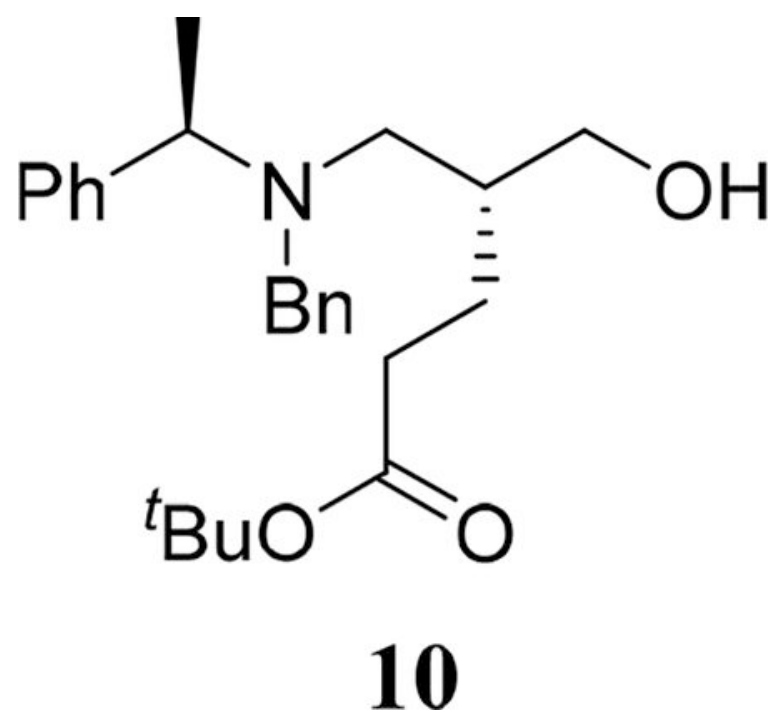

(R)-2-(Carboxyethyl-tert-butyl ester)-3-(R)-(N-benzyl-amethylbenzylamino)propan-1-ol (10): Compound 9 was converted to 10 by the following 4-step sequence.

Step 1 (TBS protection): To a solution of 9 ( $5.4 \mathrm{~g}, 15 \mathrm{mmol})$ in $50 \mathrm{ml} \mathrm{CH}_{2} \mathrm{Cl}_{2}$ was added $\mathrm{TBSCl}(2.8 \mathrm{~g}, 18 \mathrm{mmol})$ and imidazole $(2 \mathrm{~g}, 30 \mathrm{mmol})$. The mixture was stirred overnight at room temperature. The mixture was then diluted with $\mathrm{CH}_{2} \mathrm{Cl}_{2}$ and washed with brine. The organic layer was separated, dried over anhydrous $\mathrm{MgSO}_{4}$, and concentrated. The residue was purified by column chromatography ( $5 \%$ ethyl acetate in hexane) to afford the TBS protection product as colorless oil in $97 \%$ yield. ${ }^{1} \mathrm{H}$ NMR $\left(300 \mathrm{MHz}, \mathrm{CDCl}_{3}\right) \delta 7.38-7.15$ $(\mathrm{m}, 10 \mathrm{H}), 3.90(\mathrm{q}, J=6.9 \mathrm{~Hz}, 1 \mathrm{H}), 3.65(\mathrm{~s}, 3 \mathrm{H}), 3.59(\mathrm{~d}, J=13.8 \mathrm{~Hz}, 1 \mathrm{H}), 3.55(\mathrm{dd}, J=$ $10.0,3.8 \mathrm{~Hz}, 1 \mathrm{H}), 3.41(\mathrm{~d}, J=13.8 \mathrm{~Hz}, 1 \mathrm{H}), 3.19$ (dd, $J=10.0,5.1 \mathrm{~Hz}, 1 \mathrm{H}), 2.44-2.17(\mathrm{~m}$, $4 \mathrm{H}), 1.75-1.60(\mathrm{~m}, 3 \mathrm{H}), 1.38(\mathrm{~d}, J=6.9 \mathrm{~Hz}, 3 \mathrm{H}), 0.85(\mathrm{~s}, 9 \mathrm{H}),-0.01(\mathrm{~s}, 3 \mathrm{H}),-0.03(\mathrm{~s}, 3 \mathrm{H})$. HRMS (ESI): $[\mathrm{M}+\mathrm{H}]^{+}$calculated 470.3085, found 470.3083 .

Step 2 (methyl ester deprotection): The TBS protection product $(2.1 \mathrm{~g}, 4.5 \mathrm{mmol})$ from step 1 was dissolved in $5 \mathrm{ml} \mathrm{MeOH}$ and $5 \mathrm{ml} \mathrm{THF}$. To this solution were added $5 \mathrm{ml}$ water and $\mathrm{KOH}(0.75 \mathrm{~g}, 13.5 \mathrm{mmol})$. The resulting mixture was stirred at room temperature for 8 hours. The mixture was then diluted with ethyl acetate and washed with $5 \%$ aqueous citric acid. The organic layer was separated and the aqueous layer was extracted several times with ethyl acetate. All organic layers were combined, dried over anhydrous $\mathrm{MgSO}_{4}$, and concentrated to afford material that was directly used for the next step.

Step 3 (formation of tert-butyl ester): The crude product from step 2 was dissolved in $20 \mathrm{ml}$ $\mathrm{CH}_{2} \mathrm{Cl}_{2}$. To this solution were added EDCI (2.6 g, $\left.13.5 \mathrm{mmol}\right)$, DMAP (1.1 g, $\left.9 \mathrm{mmol}\right)$, triethylamine $(1.2 \mathrm{ml}, 9 \mathrm{mmol})$ and tert-butanol $(3.5 \mathrm{~g}, 45 \mathrm{mmol})$. This mixture was stirred at 
room temperature for 14 hours. The mixture was then diluted with $\mathrm{CH}_{2} \mathrm{Cl}_{2}$, and washed sequentially with $5 \%$ citric acid and saturated $\mathrm{NaCl}$ solution. The organic layer was separated, dried over anhydrous $\mathrm{MgSO}_{4}$, and concentrated to afford material that was directly used for the next step.

Step 4 (TBS deprotection): The crude tert-butyl ester from step 3 was dissolved in $10 \mathrm{ml}$ THF and transferred to a plastic reaction vessel. This solution was cooled in an ice-bath and $9.5 \mathrm{ml}$ TBAF solution ( $1 \mathrm{M}$ in THF) was added. The mixture was stirred for 3 hours at room temperature. To the solution were added ethyl acetate and water. The organic layer was separated, and the aqueous layer was extracted with ethyl acetate several times. All organic layers were combined, dried over anhydrous $\mathrm{MgSO}_{4}$, and concentrated. The residue was purified by column chromatography ( $25 \%$ ethyl acetate in hexane) to afford $\mathbf{1 0}$ as colorless oil (1.2 g, 67\% yield over three steps). ${ }^{1} \mathrm{H}$ NMR (400 MHz, $\left.\mathrm{CDCl}_{3}\right) \delta 7.37-7.23(\mathrm{~m}, 10 \mathrm{H})$, $4.65(\mathrm{~s}, 1 \mathrm{H}), 4.01(\mathrm{q}, J=6.9 \mathrm{~Hz}, 1 \mathrm{H}), 3.89(\mathrm{~d}, J=13.2 \mathrm{~Hz}, 1 \mathrm{H}), 3.55(\mathrm{~m}, 1 \mathrm{H}), 3.37(\mathrm{~d}, J=$ $13.2 \mathrm{~Hz}, 1 \mathrm{H}), 3.02(\mathrm{dd}, J=10.8,8.3 \mathrm{~Hz}, 1 \mathrm{H}), 2.56(\mathrm{~m}, 1 \mathrm{H}), 2.45(\mathrm{dd}, J=12.8,10.8 \mathrm{~Hz}, 1 \mathrm{H})$, $2.18(\mathrm{t}, J=7.7 \mathrm{~Hz}, 2 \mathrm{H}), 1.94-1.84(\mathrm{~m}, 1 \mathrm{H}), 1.42(\mathrm{~s}, 9 \mathrm{H}), 1.36(\mathrm{~d}, J=6.9 \mathrm{~Hz}, 3 \mathrm{H}), 1.40-1.30$ $(\mathrm{m}, 2 \mathrm{H}) .{ }^{13} \mathrm{C}\left\{{ }^{1} \mathrm{H}\right\} \mathrm{NMR}\left(125 \mathrm{MHz}, \mathrm{CDCl}_{3}\right) \delta 173.0,142.6,138.9,129.4,128.7,128.4$, $128.3,127.5,127.3,80.5,67.4,56.4,55.1,54.0,36.5,33.4,28.2,25.3,9.6$. HRMS (ESI): $[\mathrm{M}+\mathrm{H}]^{+}$calculated 398.2690, found 398.2689.
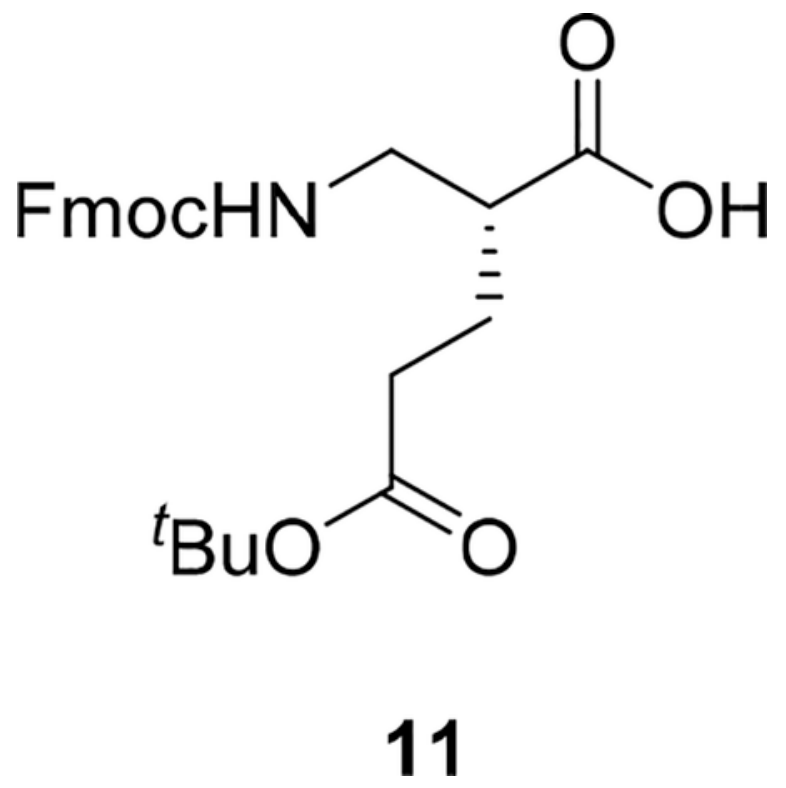

(R)-2-(Carboxyethyl-tert-butyl ester)-3-(9-fluorenylmethylcarbamate)propanoic acid (11): To a solution of $\mathbf{1 0}(0.8 \mathrm{~g}, 2 \mathrm{mmol})$ in $20 \mathrm{ml}$ ethanol were added $0.21 \mathrm{~g} \mathrm{Pd} / \mathrm{C}(10$ wt. \% loading), $0.14 \mathrm{~g} \mathrm{Pd}(\mathrm{OH})_{2} / \mathrm{C}$ (20\% wt. \% loading) and ammonium formate (1.2 g, 20 $\mathrm{mmol})$. The mixture was stirred for 6 hours at $60^{\circ} \mathrm{C}$ under nitrogen atmosphere. After the hydrogenolysis was complete, the reaction mixture was filtered through celite, and the celite was washed several times with methanol. The methanol solutions were combined and concentrated. The resulting residue was dissolved in $15 \mathrm{ml} \mathrm{CH}_{2} \mathrm{Cl}_{2}$ with Fmoc-OSu (0.68 g, $2 \mathrm{mmol})$ and DIEA $(0.35 \mathrm{ml}, 2 \mathrm{mmol})$. This solution was stirred for 2 hours at room temperature. The reaction mixture was diluted with $\mathrm{CH}_{2} \mathrm{Cl}_{2}$ and washed several times with 
brine. The organic layer was separated, dried over anhydrous $\mathrm{MgSO}_{4}$, and concentrated. The residue was purified by column chromatography (25-35\% ethyl acetate in hexane) to afford the desired product as a colorless oil in $75 \%$ yield. ${ }^{1} \mathrm{H}$ NMR $\left(400 \mathrm{MHz}, \mathrm{CDCl}_{3}\right) \delta 7.77(\mathrm{~d}, J$ $=7.4 \mathrm{~Hz}, 2 \mathrm{H}), 7.59(\mathrm{~d}, J=7.4 \mathrm{~Hz}, 2 \mathrm{H}), 7.40(\mathrm{t}, J=7.4 \mathrm{~Hz}, 2 \mathrm{H}), 7.32(\mathrm{td}, J=7.4,1.2 \mathrm{~Hz}$, $2 \mathrm{H}), 5.22(\mathrm{t}, J=6.5 \mathrm{~Hz}, 1 \mathrm{H}), 4.43(\mathrm{~d}, J=6.9 \mathrm{~Hz}, 2 \mathrm{H}), 4.22(\mathrm{t}, J=6.9 \mathrm{~Hz}, 1 \mathrm{H}), 3.56-3.50$ (m, 2H), 3.44-3.30 (m, 2H), 3.25-3.05 (m, 2H), 2.37-2.24 (m, 2H), 1.63-1.50 (m, 3H), 1.45 (s, 9H). ${ }^{13} \mathrm{C}\left\{{ }^{1} \mathrm{H}\right\}$ NMR $\left(125 \mathrm{MHz}, \mathrm{CDCl}_{3}\right) \delta 173.5,157.9,143.97,143.95,141.5,127.9$, $127.2,125.1,120.1,80.8,67.0,62.2,47.4,41.3,41.1,33.1,28.2,23.2$. The spectral data for this compound were consistent with those of its enantiomer. ${ }^{10}$

The Fmoc-protected amino alcohol was converted to 11 via $\mathrm{RuCl}_{3} / \mathrm{NaIO}_{4}$ oxidation. A round-bottom flask was charged with $4 \mathrm{ml}$ carbon tetrachloride, $4 \mathrm{ml}$ acetonitrile, $6 \mathrm{ml}$ water, the Fmoc-protected amino alcohol $(0.58 \mathrm{~g}, 1.35 \mathrm{mmol})$ and $\mathrm{NaIO}_{4}(1.3 \mathrm{~g}, 6.1 \mathrm{mmol})$. To the above mixture was added $\mathrm{RuCl}_{3}(10 \mathrm{mg}, 0.034 \mathrm{mmol})$. This mixture was stirred at room temperature until TLC analysis revealed complete conversion of the starting alcohol. The reaction mixture was then diluted with ethyl acetate and the remaining oxidant was quenched by $0.5 \mathrm{~N}$ aqueous $\mathrm{Na}_{2} \mathrm{~S}_{2} \mathrm{O}_{3}$. The organic layer was separated, and the aqueous layer was extracted several times with ethyl acetate. All organic layers were combined, dried over anhydrous $\mathrm{MgSO}_{4}$, filtered through celite, and concentrated. The residue was purified by column chromatography (35\% ethyl acetate in hexane with $1 \%$ acetic acid) to afford $\mathbf{1 1}$ as white solid in $70 \%$ yield. ${ }^{1} \mathrm{H}$ NMR $\left(300 \mathrm{MHz}\right.$, DMSO- $\left.d_{6}\right) \delta 12.35(\mathrm{~s}, 1 \mathrm{H}), 7.88(\mathrm{~d}, J=$ $7.4 \mathrm{~Hz}, 2 \mathrm{H}), 7.69(\mathrm{~d}, J=7.4 \mathrm{~Hz}, 2 \mathrm{H}), 7.49-7.39(\mathrm{~m}, 3 \mathrm{H}), 7.32(\mathrm{td}, J=7.4,1.3 \mathrm{~Hz}, 2 \mathrm{H})$, 4.33-4.18 (m, 3H), $3.21(\mathrm{~m}, 1 \mathrm{H}), 3.07(\mathrm{~m}, 1 \mathrm{H}), 2.44(\mathrm{~m}, 1 \mathrm{H}), 2.30-2.10(\mathrm{~m}, 2 \mathrm{H}), 1.72-1.59$ (m, 2H), $1.38(\mathrm{~s}, 9 \mathrm{H}) .{ }^{13} \mathrm{C}\left\{{ }^{1} \mathrm{H}\right\}$ NMR $\left(100 \mathrm{MHz}\right.$, DMSO- $\left.d_{6}\right) \delta 174.9,171.7,156.1,143.9$, $140.7,127.6,127.1,125.2,120.1,79.6,65.4,46.7,44.3,41.9,32.4,27.7,24.3 .[a]_{D}{ }^{20}=$ $-1.0\left(\mathrm{c}=2.7, \mathrm{CHCl}_{3}\right)$. The spectral data for $\mathbf{1 1}$ were consistent with those of Fmoc- $\left(\mathrm{S}^{*}\right)-\beta^{2}$ hGlu. ${ }^{10}$

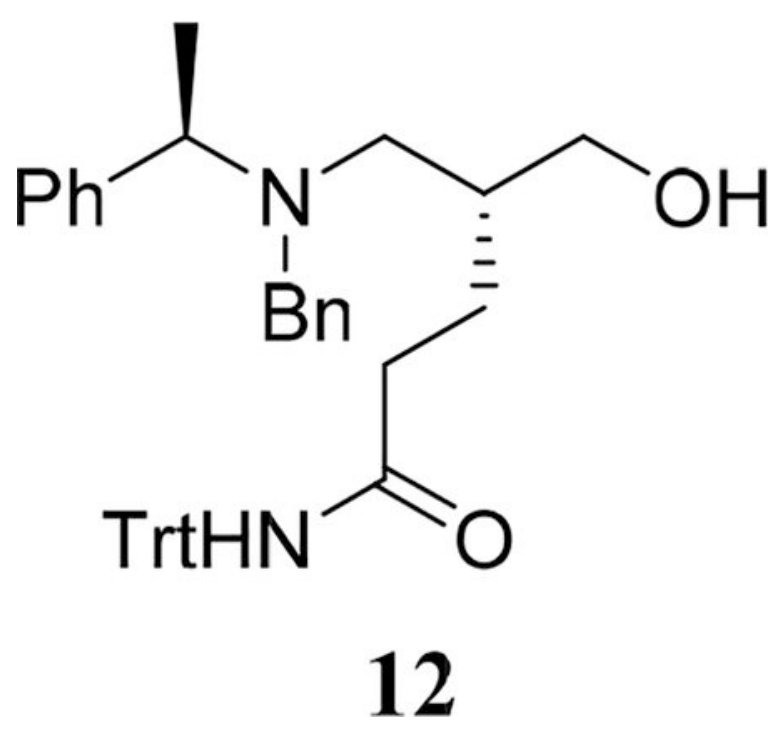

(R)-2-(Carboxyethyl-triphenylmethyl amide)-3-(R)-(N-benzyl-amethylbenzylamino)propan-1-ol (12): Prepared from 9 by a 4 -step sequence. 
Step 1 (TBS protection): See step 1 in the synthesis of $\mathbf{1 0 .}$

Step 2 (methyl ester hydrolysis): The TBS protection product $(1.02 \mathrm{~g}, 2.2 \mathrm{mmol}$ ) from step 1 was dissolved in $5 \mathrm{ml} \mathrm{MeOH}$ and $5 \mathrm{ml}$ THF. To the above solution were added $5 \mathrm{ml}$ water and $\mathrm{KOH}(0.49 \mathrm{~g}, 8.7 \mathrm{mmol})$. See step 2 in the synthesis of $\mathbf{1 0}$ for the experimental details.

Step 3 (formation of trityl amide): The crude product from step 2 was dissolved in $10 \mathrm{ml}$ DMF. To the above solution was added HATU $(1.2 \mathrm{~g}, 3.2 \mathrm{mmol})$ and triethylamine $(0.62 \mathrm{ml}$, $4.4 \mathrm{mmol})$. The mixture was stirred at room temperature for $40 \mathrm{~min}$. Trityl amine $(0.83 \mathrm{~g}$, $3.2 \mathrm{mmol}$ ) was then added to the solution. The reaction mixture was stirred for $30 \mathrm{~h}$ at $60{ }^{\circ} \mathrm{C}$. The solution was then diluted with ethyl acetate, and washed sequentially with $5 \%$ aqueous citric acid and saturated aqueous $\mathrm{NaCl}$. The organic layer was separated, dried over anhydrous $\mathrm{MgSO}_{4}$, and concentrated to afford material that was directly used for the next step.

Step 4 (TBS deprotection): The crude trityl amide from step 3 was dissolved in $10 \mathrm{ml}$ THF and transferred to a plastic reaction vessel. This solution was cooled in ice-bath, and $\mathrm{TBAF} \bullet 3 \mathrm{H}_{2} \mathrm{O}(0.68 \mathrm{~g}, 2.2 \mathrm{mmol})$ was added. The reaction mixture was stirred for 3 hours at room temperature. To this solution was added ethyl acetate and water. The organic layer was separated, and the aqueous layer was extracted with ethyl acetate several times. All organic layers were combined, dried over anhydrous $\mathrm{MgSO}_{4}$, and concentrated. The residue was purified by column chromatography (20-25\% ethyl acetate in hexane with $1 \%$ triethylamine) to afford $\mathbf{1 2}$ as a white solid (41\% yield over four steps). ${ }^{1} \mathrm{H}$ NMR (400 MHz, $\left.\mathrm{CDCl}_{3}\right) \delta 7.35-7.10(\mathrm{~m}, 25 \mathrm{H}), 6.53(\mathrm{~s}, 1 \mathrm{H}), 3.97(\mathrm{q}, J=6.9 \mathrm{~Hz}, 1 \mathrm{H}), 3.80(\mathrm{~d}, J=13.1 \mathrm{~Hz}$, $1 \mathrm{H}), 3.51(\mathrm{dd}, J=10.8,2.5 \mathrm{~Hz}, 1 \mathrm{H}), 3.35(\mathrm{~d}, J=13.1 \mathrm{~Hz}, 1 \mathrm{H}), 3.03(\mathrm{dd}, J=10.8,7.7 \mathrm{~Hz}$, $1 \mathrm{H}), 2.47(\mathrm{dd}, J=13.0$ and $3.4 \mathrm{~Hz}, 1 \mathrm{H}), 2.40(\mathrm{dd}, J=13.0,10.6 \mathrm{~Hz}, 1 \mathrm{H}), 2.25-2.15(\mathrm{~m}, 2 \mathrm{H})$, $1.82(\mathrm{~m}, 1 \mathrm{H}), 1.50-1.40(\mathrm{~m}, 1 \mathrm{H}), 1.33(\mathrm{~d}, J=6.9 \mathrm{~Hz}, 3 \mathrm{H}), 1.30-1.20(\mathrm{~m}, 1 \mathrm{H}) .{ }^{13} \mathrm{C}\left\{{ }^{1} \mathrm{H}\right\}$ NMR $\left(125 \mathrm{MHz}, \mathrm{CDCl}_{3}\right) \delta 171.6,144.8,129.3,128.8,128.6,128.32,128.30,128.1,127.4$, 127.3, 127.2, 70.6, 66.8, 56.4, 55.0, 53.7, 36.7, 35.2, 25.4, 9.8. HRMS (ESI): $[\mathrm{M}+\mathrm{H}]^{+}$ calculated 583.3319, found 583.3318 . 


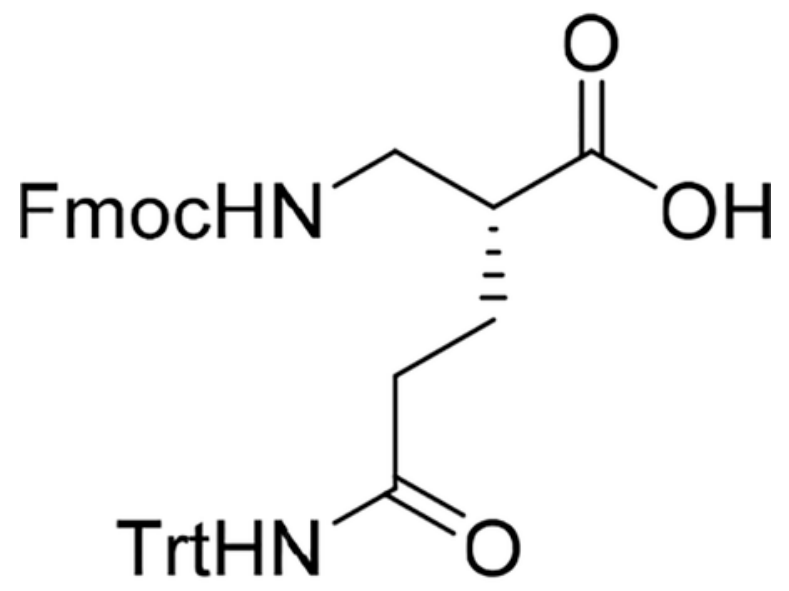

13

(R)-2-(Carboxyethyl-triphenylmethyl amide)-3-(9-

fluorenylmethylcarbamate)propanoic acid (13): To a solution of $\mathbf{1 2}(0.23 \mathrm{~g}, 0.4$ $\mathrm{mmol})$ in $5 \mathrm{ml}$ ethanol was added $85 \mathrm{mg} \mathrm{Pd} / \mathrm{C}$ (10 wt. \% loading), $56 \mathrm{mg} \mathrm{Pd}(\mathrm{OH})_{2} / \mathrm{C}(20 \%$ wt. \% loading), ammonium formate $(0.25 \mathrm{~g}, 4 \mathrm{mmol})$. The resulting mixture was stirred for 7 hours at $60^{\circ} \mathrm{C}$ under nitrogen. After the hydrogenolysis was complete, the reaction mixture was filtered through celite, and the celite was washed several times with methanol. The methanol solutions were combined and concentrated. The residue was dissolved in 10 $\mathrm{ml} \mathrm{CH}_{2} \mathrm{Cl}_{2}$ with Fmoc-OSu $(0.14 \mathrm{~g}, 0.4 \mathrm{mmol})$ and DIEA ( $\left.70 \mu \mathrm{l}, 0.4 \mathrm{mmol}\right)$. The above solution was stirred for 2 hours at room temperature. The reaction mixture was diluted with $\mathrm{CH}_{2} \mathrm{Cl}_{2}$ and washed with $5 \%$ aqueous citric acid and saturated aqueous $\mathrm{NaCl}$. The organic layer was separated, dried over anhydrous $\mathrm{MgSO}_{4}$, and concentrated. The residue was purified by column chromatography (5\% MeOH in DCM) to yield the desired Fmocprotected amino alcohol in $84 \%$ yield. ${ }^{1} \mathrm{H}$ NMR $\left(400 \mathrm{MHz}, \mathrm{CDCl}_{3}\right) \delta 7.75(\mathrm{~d}, J=7.4 \mathrm{~Hz}$, 2H), 7.55 (d, $J=7.4,2 \mathrm{H}), 7.39$ (t, $J=7.4 \mathrm{~Hz}, 2 \mathrm{H}), 7.35-7.15(\mathrm{~m}, 17 \mathrm{H}), 6.74(\mathrm{~s}, 1 \mathrm{H}), 5.19$ (t, $J=6.6 \mathrm{~Hz}, 1 \mathrm{H}), 4.32(\mathrm{~d}, J=6.9 \mathrm{~Hz}, 2 \mathrm{H}), 4.16(\mathrm{t}, J=6.9 \mathrm{~Hz}, 1 \mathrm{H}), 3.42(\mathrm{dd}, J=11.8,3.6 \mathrm{~Hz}$, $1 \mathrm{H}), 3.32-3.22(\mathrm{~m}, 2 \mathrm{H}), 2.95-2.85(\mathrm{~m}, 1 \mathrm{H}), 2.50-2.25(\mathrm{~m}, 2 \mathrm{H}), 1.53(\mathrm{~m}, 3 \mathrm{H}), 0.87(\mathrm{~s}, 1 \mathrm{H})$. HRMS (ESI): $[\mathrm{M}+\mathrm{H}]^{+}$calculated 611.2904, found 611.2902.

The above Fmoc-protected amino alcohol was converted to 13 via Jones oxidation. A solution of Fmoc-protected amino alcohol $(0.19 \mathrm{~g}, 0.3 \mathrm{mmol})$ in $5 \mathrm{ml}$ acetone was added dropwise to $0.6 \mathrm{mmol} \mathrm{H}_{2} \mathrm{Cr}_{2} \mathrm{O}_{7}$ (prepared by mixing $\mathrm{Na}_{2} \mathrm{Cr}_{2} \mathrm{O}_{7} \cdot 2 \mathrm{H}_{2} \mathrm{O}$ and $\mathrm{H}_{2} \mathrm{SO}_{4}$ ) in $3 \mathrm{ml}$ acetone at $0{ }^{\circ} \mathrm{C}$. The reaction mixture was stirred for 2 hours. Excess isopropanol was then added to quench remaining oxidant. To this mixture were added ethyl acetate and water. The organic layer was separated, and the aqueous layer was extracted with ethyl acetate several times. All organic layers were combined, washed with brine, dried over anhydrous $\mathrm{MgSO}_{4}$, filtered through celite, and concentrated. The residue was purified by column chromatography (2-5\% MeOH in DCM with $1 \%$ acetic acid) to afford $\mathbf{1 3}$ as a white solid in a $88 \%$ yield. ${ }^{1} \mathrm{H}$ NMR (300 MHz, DMSO- $\left.d_{6}\right) \delta 12.27(\mathrm{~s}, 1 \mathrm{H}), 8.59(\mathrm{~s}, 1 \mathrm{H}), 7.88(\mathrm{~d}, J=7.4$ 
$\mathrm{Hz}, 2 \mathrm{H}), 7.68(\mathrm{~d}, J=7.4 \mathrm{~Hz}, 2 \mathrm{H}), 7.41(\mathrm{t}, J=7.4 \mathrm{~Hz}, 2 \mathrm{H}), 7.34-7.10(\mathrm{~m}, 17 \mathrm{H}), 4.23(\mathrm{~m}$, $3 \mathrm{H}), 3.25-3.00(\mathrm{~m}, 2 \mathrm{H}), 2.42(\mathrm{~m}, 1 \mathrm{H}), 2.29(\mathrm{~m}, 2 \mathrm{H}), 1.61(\mathrm{~m}, 2 \mathrm{H}) .{ }^{13} \mathrm{C}\left\{{ }^{1} \mathrm{H}\right\}$ NMR $(125$ MHz, DMSO- $\left.d_{6}\right) \delta 175.2,171.4,156.1,144.9,143.9,140.7,128.5,127.6,127.4,127.1$, $126.3,125.2,120.1,69.1,65.4,46.7,44.8,41.9,33.5,25.1$. The spectra data were consistent with previous report. ${ }^{17}[\mathrm{a}]_{\mathrm{D}}{ }^{20}=7.6\left(\mathrm{c}=0.5, \mathrm{CHCl}_{3}\right) . \mathrm{HRMS}(\mathrm{ESI}):[\mathrm{M}-\mathrm{H}]^{-}$calculated 623.2552 , found 623.2557

\section{Supplementary Material}

Refer to Web version on PubMed Central for supplementary material.

\section{ACKNOWLEDGMENTS}

This research was supported by NIH Grant R01 GM056414. We thank Dr. Ilia Guzei for assistance with X-ray crystallography.

\section{REFERENCES}

1. Seebach D; Gardiner J, Beta-Peptidic Peptidomimetics. Acc. Chem. Res 2008, 41, 1366-1375. [PubMed: 18578513]

2. Horne WS; Gellman SH, Foldamers with Heterogeneous Backbones. Acc. Chem. Res 2008, 41, 1399-1408. [PubMed: 18590282]

3. Johnson LM; Gellman SH, Alpha-Helix Mimicry with Alpha/Beta-Peptides. Methods Enzymol 2013, 523, 407-429. [PubMed: 23422441]

4. Boersma MD; Haase HS; Peterson-Kaufman KJ; Lee EF; Clarke OB; Colman PM; Smith BJ; Horne WS; Fairlie WD; Gellman SH, Evaluation of Diverse Alpha/Beta-Backbone Patterns for Functional Alpha-Helix Mimicry: Analogues of the Bim BH3 Domain. J. Am. Chem. Soc 2012, 134, 315-323. [PubMed: 22040025]

5. Liu S; Cheloha RW; Watanabe T; Gardella TJ; Gellman SH, Receptor Selectivity from Minimal Backbone Modification of a Polypeptide Agonist. Proc. Natl. Acad. Sci. U.S.A 2018, 115, 1238312388. [PubMed: 30442659]

6. Liu S; Jean-Alphonse FG; White AD; Wootten D; Sexton PM; Gardella TJ; Vilardaga JP; Gellman $\mathrm{SH}$, Use of Backbone Modification to Enlarge the Spatiotemporal Diversity of Parathyroid Hormone Receptor-1 Signaling via Biased Agonism. J. Am. Chem. Soc 2019, 141, 14486-14490. [PubMed: 31496241]

7. Seebach D; Beck AK; Capone S; Deniau G; Groselj U; Zass E, Enantioselective Preparation of Beta(2)-Amino Acid Derivatives for Beta-Peptide Synthesis. Synthesis 2009, 1, 1-32.

8. Seebach D; Schaeffer L; Gessier F; Bindschadler P; Jager C; Josien D; Kopp S; Lelais G; Mahajan YR; Micuch P; Sebesta R; Schweizer BW, Enantioselective Preparation of 2-Aminomethyl Carboxylic Acid Derivatives: Solving the Beta(2)-Amino Acid Problem with the Chiral Auxiliary 4Isopropyl-5,5-Diphenyloxazolidin-2-one (DIOZ) - Preliminary Communication. Helv. Chim. Acta 2003, 86, 1852-1861.

9. Chi YG; Gellman SH, Enantioselective Organocatalytic Aminomethylation of Aldehydes: A Role for Ionic Interactions and Efficient Access to beta(2)-amino acids. J. Am. Chem. Soc 2006, 128, 6804-6805. [PubMed: 16719457]

10. Chi Y; English EP; Pomerantz WC; Horne WS; Joyce LA; Alexander LR; Fleming WS; Hopkins EA; Gellman SH, Practical Synthesis of Enantiomerically Pure Beta(2)-Amino Acids via ProlineCatalyzed Diastereoselective Aminomethylation of Aldehydes. J. Am. Chem. Soc 2007, 129, 6050-6055. [PubMed: 17439122]

11. Li Y; Manickam G; Ghoshal A; Subramaniam P, More Efficient Palladium Catalyst for Hydrogenolysis of Benzyl Groups. Synth. Commun 2006, 36, 925-928.

12. McDougal PG; Rico JG; Oh YI; Condon BD, A Convenient Procedure for The Monosilylation of Symmetrical 1, n-Diols. J. Org. Chem 1986, 51, 3388-3390. 
13. Hoover JM; Steves JE; Stahl SS, Copper(I)/TEMPO-Catalyzed Aerobic Oxidation of Primary Alcohols to Aldehydes with Ambient Air. Nat Protoc 2012, 7, 1161-1166 [PubMed: 22635108]

14. Li XJ; Lantrip D; Fuchs PL, Gamma-Allyl Phosphinoyl Phenyl Sulfone (GAPPS): A Conjunctive Reagent for the Synthesis of EE, EZ, and ET 1,3-Dienes. J. Am. Chem. Soc 2003, 125, 1426214263. [PubMed: 14624559]

15. Carlsen PHJ; Katsuki T; Martin VS; Sharpless KB, A Greatly Improved Procedure for Ruthenium Tetraoxide Catalyzed Oxidation of Organic Compounds. J. Org. Chem 1981, 46, 3936-3938.

16. Cook C; Liron F; Guinchard X; Roulland E, Study of the Total Synthesis of (-)-Exiguolide. J. Org. Chem 2012, 77, 6728-6742. [PubMed: 22849583]

17. Lelais G; Campo MA; Kopp S; Seebach D, Enantioselective Preparation of Beta(2)-Amino Acids with Aspartate, Glutamate, Asparagine, and Glutamine Side Chains. Helv. Chim. Acta 2004, 87, 1545-1560. 
<smiles>[Z6]C(=O)C([R])NC(C)(C)C</smiles>

(L)-o-residue<smiles>[R]C(CNC)C(=O)C(C)(C)C</smiles>

$\left(R^{*}\right)-\beta^{2}$-residue<smiles>[R]C(CNC)C(=O)C(C)(C)C</smiles>

$\left(S^{*}\right)-\beta^{2}$-residue<smiles>[R]C(CC(C)C)NC(C)=O</smiles>

$\left(R^{*}\right)-\beta^{3}$-residue<smiles>[R]C(CC(C)C)N[14CH3]</smiles>

$\left(S^{*}\right)-\beta^{3}$-residue

Figure 1:

Generic structures of homologous $\beta$-amino-acid residues; a generic L-a residue is shown for comparison. Proteinogenic L-a residues have $S$ configuration, but the homologous $\beta^{2}$ and $\beta^{3}$ residues have varying configurations depending upon side chain identity. The designations $S^{*}$ and $R^{*}$ are applied to $\beta^{2}$ and $\beta^{3}$ residues as shown, based on the absolute configurations of the $\beta^{2}$ - and $\beta^{3}$-hAla enantiomers. 
a.

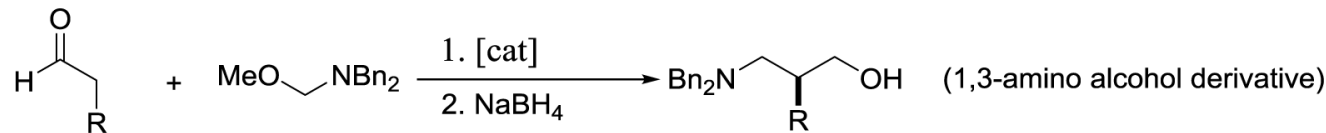

1. $\mathrm{Pd} / \mathrm{C}, \mathrm{NH}_{4} \mathrm{HCO}_{2}$

2. FmocOSu, Base

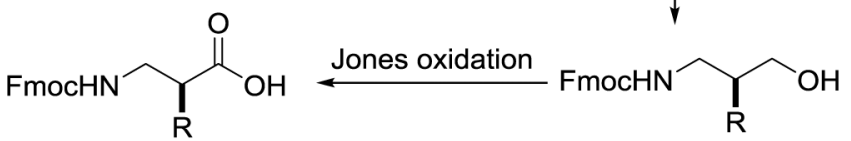

b.
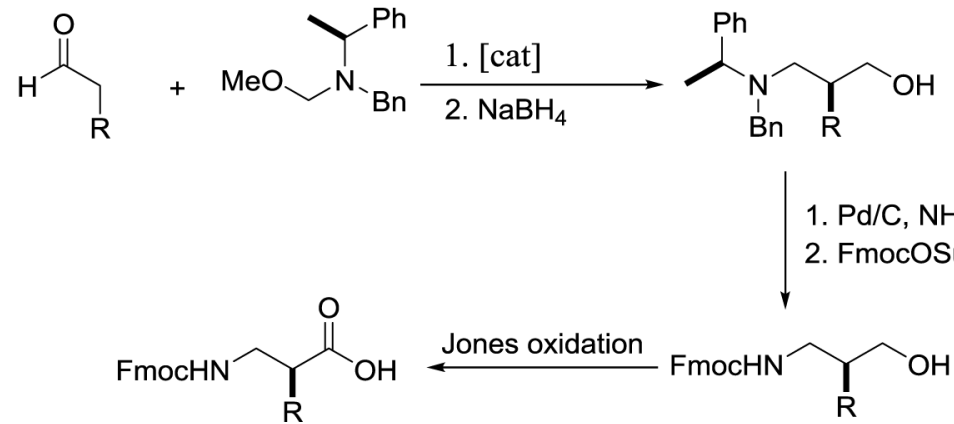

Figure 2:

Preparation of homologous $\beta^{2}$-amino acids via organocatalytic Mannich reaction. [cat] represents the Jorgensen-Hayashi catalyst (a) or proline (b). 


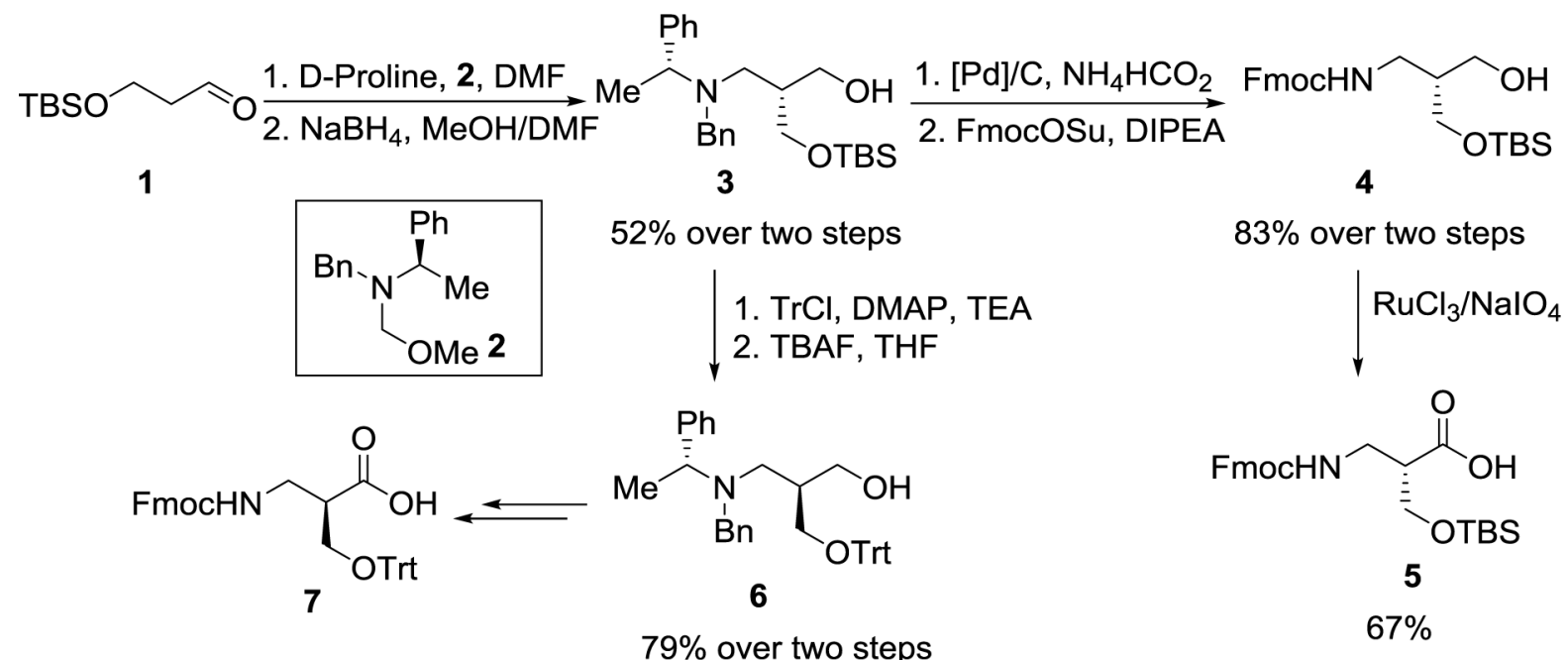

Figure 3.

Collective synthesis of both enantiomers of a protected $\beta^{2}$-hSer building block. 
<smiles>COC(=O)CCCC=O</smiles>

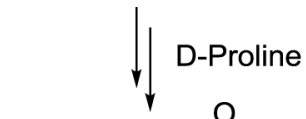<smiles>[3H]C[C@H](CO)CCC(=O)OC</smiles><smiles>CC(c1ccccc1)N(C)Cc1ccccc1</smiles>

$45 \%$
1. TBSCl, Imidazole 2. $\mathrm{KOH}, \mathrm{THF} / \mathrm{H}_{2} \mathrm{O} / \mathrm{MeOH}$ 3. EDCI, DMAP, $t$-BuOH 4.TBAF, THF

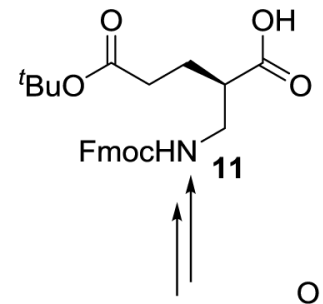<smiles>CCCCC(=O)OCCC(CO)CN=Cc1ccccc1</smiles><smiles>CCCN[AlH2]</smiles>

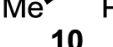
$63 \%$ over 4 steps

1. TBSCI, Imidazole

2. $\mathrm{KOH}, \mathrm{THF} / \mathrm{H}_{2} \mathrm{O} / \mathrm{MeOH}$

3. $\mathrm{TrNH}_{2}, \mathrm{HATU}$, TEA 4.TBAF, THF
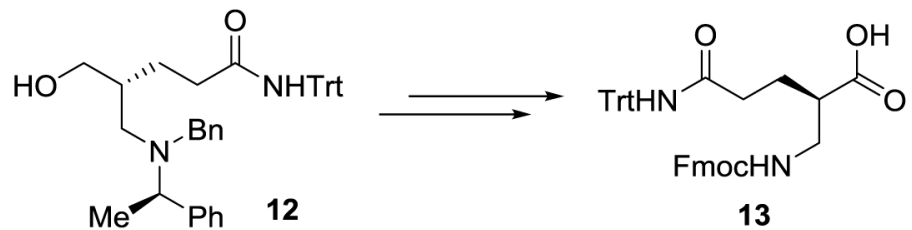

$41 \%$ over 4 steps

Figure 4:

Collective synthesis of protected $\beta^{2}$-hGlu and $\beta^{2}$-hGln building blocks. 